\title{
Valvar replacement in infants and preschool children: a retrospective single-center study
}

\author{
G Liguori", A Kanas, J Penha, L Miana, L Caneo, C Tanamati, M Jatene \\ From 23rd World Congress of the World Society of Cardio-Thoracic Surgeons \\ Split, Croatia. 12-15 September 2013
}

\section{Background}

The use of prosthetic valves in children is controversial, being indicated only if valve repair is not possible. In this study, we sought to report and evaluate the immediate and long-term outcomes of our experience in valvar replacement in infants and preschool children.

\section{Methods}

We conducted a retrospective study of 16 infants and preschoolers patients who undergone valve replacement between 1997 and 2006. We analyzed medical records, echocardiographic exams and surgical reports.

\section{Results}

Mean age at surgery was $11.7 \pm 10.4(\min =0.8, \max =$ 32.9) months. Diagnoses were isolated congenital valvopathy (38\%), atrioventricular septal defect (AVSD) (31\%), common arterial trunk (19\%) and tetralogy of Fallot $(12 \%)$. Nine $(50 \%)$ of the prostheses were located in mitral, $4(22 \%)$ in aortic, $2(11 \%)$ in pulmonary and $3(17 \%)$ in truncal position. Five $(31.3 \%)$ patients underwent reoperation during the follow-up period and the major indication was prosthetic valve stenosis. The mean time free of reoperation was $76.5 \pm 18.8$ months. Hospital mortality was $43.8 \%$ and the average survival time $58.4 \pm$ 9.3 months. Statistically significant association was found between age at surgery and the occurrence of intra-hospital death, the younger the patient, the greater the risk of dying during the first month after the surgery $(\mathrm{p}=$ 0.026). There were differences between the intra-hospital mortality risks according to the underlying congenital heart disease, although this difference was not statistically significant $(\mathrm{p}=0.084)$. Valvopathies due to other cardiac

\footnotetext{
* Correspondence: gabrielliguori@gmail.com

Heart Institute (InCor), University of Sao Paulo Medical School, Sao Paulo,
} Brazil

(c) 2013 Liguori et al; licensee BioMed Central Ltd. This is an Open Access article distributed under the terms of the Creative Commons Attribution License (http://creativecommons.org/licenses/by/2.0), which permits unrestricted use, distribution, and reproduction in any medium, provided the original work is properly cited. preschool children: a retrospective single-center study. Journal of Cardiothoracic Surgery 2013 8(Suppl 1):P173.

defects (AVSD, common arterial trunk and tetralogy of Fallot) had higher occurrence of intra-hospital death.

\section{Conclusion}

Valve replacement in infants and children in preschool age, although should be reserved for cases in which there is no possibility of valvuloplasty, proved to be an immediate therapeutic alternative. Still, reoperations are needed and the duration of the valve prosthesis quite variable.

Published: 11 September 2013

Submit your next manuscript to BioMed Central and take full advantage of:

- Convenient online submission

- Thorough peer review

- No space constraints or color figure charges

- Immediate publication on acceptance

- Inclusion in PubMed, CAS, Scopus and Google Scholar

- Research which is freely available for redistribution
Cite this article as: Liguori et al:: Valvar replacement in infants and 